\title{
Assessment of Knowledge, Attitude and Practice of the General Population of Bukavu in the Democratic Republic of Congo on Blood Donation and Blood Transfusion
}

\author{
Jeff Maotela Kabinda 1,2,3, Serge Ahuka Miyanga', Sylvain Yuma Ramazani', \\ Michèle-Wilmet Dramaix ${ }^{3,5,6}$ \\ ${ }^{1}$ Provincial Blood Transfusion Centre of Bukavu, Bukavu, Democratic Republic of Congo \\ ${ }^{2}$ Catholic University of Bukavu, Bukavu, Democratic Republic of Congo \\ ${ }^{3}$ Research Centre in Biostatistics and Epidemiology, Brussels, Belgium \\ ${ }^{4}$ National Blood Transfusion Centre of Kinshasa, Kinshasa, Democratic Republic of Congo \\ ${ }^{5}$ Free University of Brussels, Brussels, Belgium \\ ${ }^{6}$ School of Public Health, Brussels, Belgium \\ Email: kabindaalu@yahoo.fr
}

Received 16 August 2014; revised 1 October 2014; accepted 16 October 2014

Copyright (C) 2014 by authors and Scientific Research Publishing Inc.

This work is licensed under the Creative Commons Attribution International License (CC BY). http://creativecommons.org/licenses/by/4.0/

(c) (i) Open Access

\section{Abstract}

Objective: To assess the knowledge, attitudes and practices regarding blood donation in the general population. Methods: A cross-sectional study was conducted and enrolled 416 people between 18 and 65 years old at random, living in three health zones in the city of Bukavu in eastern DRC. These subjects responded to a questionnaire on knowledge, attitudes and practices regarding blood donation. Results: Our sample consisted of $61.5 \%$ men, $70.9 \%$ of people from one level of education at the secondary level and $60 \%$ unemployed. According to the surveyed subjects blood was considered as a fuel of the body in $44.6 \%$ and as a source of life in $44.1 \%$. Sixty-one percent of the population did not know the practice of blood donation; this knowledge differed significantly $(p<0.0001)$ according to the level of education. $67.1 \%$ of people knew that the blood had negative effects and $\mathbf{2 7 . 4 \%}$ did not know where the blood bags were stored. Channels of knowledge about blood donation practices were associations of blood donors $(30.9 \%)$, awareness campaigns (18.2\%), school (17.3\%) and media (15.5\%), churches $(10 \%)$, and friends $(8.1 \%)$. Approximately $85 \%$ of subjects who knew blood donation agreed with blood donation and blood transfusion but only $54.9 \%$ had donated blood in their lifetime, with a proportion of loyalty to blood donation (31.8\%). In the population $59.4 \%$ were willing to donate blood. Motivation to donate blood most common (66\%) was volunteerism while $19.1 \%$ were willing to donate blood for a 
family member and $\mathbf{1 2 . 6 \%}$ willing to donate blood against money. The reasons for refusal to donate blood identified were fear of contracting diseases especially HIV, lack of information, religious beliefs, the sale of the collected blood by medical staff, and fear of test result for HIV. Conclusion: Factors of refusal to donate blood were identified. Efforts and new strategies tailored to these factors must be developed and implemented to increase blood donation.

\title{
Keywords
}

\author{
Blood Donation, Bukavu, Transfusion, Blood Donor
}

\section{Introduction}

Blood transfusion is a medical procedure that is designed to provide patients who need blood or blood products to correct a defect. It occupies a prominent place in the therapeutic arsenal of many sub-Saharan African countries where the diseases responsible for anemia are endemic [1]. Transfusion is a saving act but can cause complications several orders that can be prevented by adequate quality control.

In such complications there are viral infections HIV and hepatitis B and C. In the Democratic Republic of Congo (DRC), because prevalence in donors of HIV was $6.1 \%$ and $9.2 \%$ of HBsAg [2] the risk of infection due to transfusion should be high. Blood safety is implemented; it consists of the safety of blood products and the safety of blood transfusion practices. Among the measures to achieve the objectives of the safety of blood transfusion practices there are mobilizing communities to donate blood, recruitment, selection and retention of donors [3] [4]. The effectiveness of this measure had been well established in developed countries [5] [6] with a high level of education. Two African studies, one conducted in Togo in the general population [7] and the other made in blood donors [1] in Burkina Faso showed that the level of knowledge about transfusion was not enough to support adequate blood safety. What about the people of the DRC? No study has ever been made. To respond to this question, the present study evaluating knowledge, attitudes and practices regarding blood donation was conducted in the general population of Bukavu in eastern DRC.

\section{Methodology}

\subsection{Population and Study Framework}

It was a cross-sectional and descriptive survey, based on the population of the town of Bukavu, which is the health district of Bukavu with 583,110 inhabitants at 2010. The district is composed of three health zones: Ibanda, Bagira and Kadutu and has respectively 12, 8 and 11 health areas. After calculating the sample size according to Schwartz formula $Z^{2} p q / d^{2}$ where $Z=1.96$ (confidence level 95\%), $p$ and $q$ correspond to the proportion of knowledge of blood donation at population (0.5) and its complement and is accuracy fixed at 0.05 , the sample was heated to 420 to include $10 \%$ of non-responders. The number of individuals in the sample was selected in proportion to the population of each area and each health area. We included all areas of health three health zones. At the health area, we interviewed between 15 and 20 between 18 and 65 years in 4 blocks randomly selected people. The way forward in the street was chosen based on the direction of the pen after tossed. Subjects were interviewed in their homes, only those with an odd number were visited. Between 6 and 21 May 2010, 416 people were enrolled in the study. Overall 99\% was the rate of response on 420 interviewed.

The transfusion service in the DRC state, headed to Kinshasa by a national center and relayed in the eleven provinces by provincial centers in the administrative centers and general hospitals of 515 health zones. These structures are responsible for blood collection, qualification, storage and distribution of blood products in a defined national policy and they are also responsible for coordinating all activities related to transfusion (supervision, quality assurance, staff training). This service is supported by more than $80 \%$ by funding and multilateral cooperation bilateral. Beside that there are associations of Voluntary Blood Donors in schools, universities and in some neighborhoods, working in partnership with the transfusion service in terms of organization of mobile blood drives. 


\subsection{Method}

The survey was to submit to persons included a French administered questionnaire or, where appropriate, in local languages.

The questionnaire consisted of 14 questions: The first three questions were about sociodemographics data, then had a closed question on the design of blood, two closed-ended questions on knowledge about blood donation and blood donation awareness. Five closed or open questions on the practice of blood donation (donation motivation, willingness to donate, the reasons for refusal to donate) and a final round of 3 questions on attitudes to transfusion and knowledge about provincial blood transfusion center (PBTC).

\subsection{Statistical Analysis}

Processing and statistical data analyses were performed using the EPI-INFO 2000 software. The usual descriptive statistics: median, and 25.75 percentile proportion were used. The Pearson X2 test and Fisher's exact test were used to compare proportions.

\section{Results}

The age of respondents ranged from 18 - 65 years with a mean age of 29 years (22 - 38). About $62 \%$ of respondents were male, $70.9 \%$ of them had completed secondary education and nearly $60 \%$ did not have a job (Table 1). The dominant religions (48.3\%) were Catholicism and Protestantism. Other religions were: Bahai 0.5\%,

\begin{tabular}{|c|c|c|}
\hline & $\mathrm{n}$ & $\%$ \\
\hline Sex & 416 & \\
\hline Male & 256 & 61.5 \\
\hline Profession & 416 & \\
\hline Public sector & 35 & 8.4 \\
\hline Private sector & 133 & 32 \\
\hline Unemployed & 248 & 59.6 \\
\hline Religion & 408 & \\
\hline Catholic & 197 & 48.3 \\
\hline Protestant & 151 & 37 \\
\hline Kimbanguiste & 6 & 1.5 \\
\hline Muslim & 12 & 2.9 \\
\hline Jehovah's witnesses & 9 & 2.9 \\
\hline Brahmin & 6 & 1.5 \\
\hline Other & 4 & 0.9 \\
\hline Without religion & 19 & 4.7 \\
\hline Level of education & 416 & \\
\hline Primary & 22 & 5.3 \\
\hline Secondary & 295 & 70.9 \\
\hline University & 87 & 20.9 \\
\hline Illiterate & 12 & 2.9 \\
\hline Health zone & 416 & \\
\hline Bagira & 70 & 16.8 \\
\hline Ibanda & 220 & 52.9 \\
\hline Kadutu & 126 & 30.3 \\
\hline
\end{tabular}


0.2\% Krishna Eckankar 0.2\%.

\subsection{Knowledge about Blood Donation}

Our investigation revealed that the blood was considered a fuel of the body by $44.6 \%$, as a source of life by $44.1 \%$ and by $11.3 \%$ as sacred (Table 2). Sixty-one percent of the population did not know the practice of donating blood. Knowledge of the practice of blood donation differed significantly depending on the level of education ( $p$ $<0.001$ ) and religion (Table 3). Indeed the proportion of people with knowledge of the practice of donation increased with the level of education and was higher among Christian respondents than among non Christians. Also among those who knew the practice of donating blood $67.1 \%$ knew that the blood had adverse effects while $67.9 \%$ had never followed the sensitization organized by the transfusion service and/or associations of blood donors about donating blood. When asked what was the place of storage of blood bags collected, $65.4 \%$ said that they were kept in public hospitals and $27.4 \%$ did not know where the blood bags were stored.

Of a total of 110 people who knew the practice of donating blood, the method of acquiring knowledge about blood donation was in order: associations of blood donors (30.9\%), awareness campaigns (18.2\%) (world blood donor day on June 14 of each year and other events to promote blood donation example football match from blood donors teams), school (17.3\%), media (15.5\%), churches (10\%) and friends (8.1\%).

\section{Knowledge of the Existence of a Blood Transfusion Service}

Overall, 17 respondents out of 57 respondents gave the correct meaning of the acronym PBTC: Blood Transfusion Provincial Center. Nearly 14\% of the population knew that the Blood Transfusion Provincial Center existed. This knowledge did not differ by gender $(p=0.43)$, level of education $(p=0.38)$ and occupation $(p=0.34)$ but was significantly different statistically based knowledge whether the practice of donation $(p<0.0001)$.

\subsection{Attitudes to Blood Donation and Blood Transfusion}

Of the 162 people who knew the practice of donating $85.2 \%$ of the subjects agreed with the blood donation and blood transfusion. In the population at the moment of the survey $59.4 \%$ were willing to donate blood. When asked "what would be the motivation to make a donation" of 247 people willing to donate blood, $66.0 \%$ would be pushed by volunteering to donate blood, while $19.1 \%$ of people would be motivated to donate blood for a family member and $12.6 \%$ against money; $2 \%$ of people would give only if doctors exercised pressure. Volunteering as motivation to donate blood did not depend on the general characteristics of the subjects ( $\operatorname{sex}(p=0.17)$, occupation $(p=0.81)$, religion $(p=0.86)$ and educational level $(p=0.63)$ ).

Of a total of 169 respondents unwilling to donate blood (Table 2) we recorded the reasons for refusal to the following gift: no compensation of donors: $14.5 \%$; $43 \%$ and $164 \%$ respectively had fear of being sick after donating blood and fear the result of HIV. Eleven people (6.7\%) had religious prohibitions for blood donation; among them, two were Catholic, a person was Protestant and 8 religion of Jehovah's witnesses. Another reason given was that the nursing staff were not courteous $(0.6 \%)$ or the sale of blood by health care workers (8.5\%) and $10.3 \%$ did not give a reason for refusal.

\subsection{Practices of Blood Donation}

162 respondents who knew the practice of giving, 89 had already given blood (54.9\%), and 73 were non-blood donors $45.1 \%$. The distribution of the number of blood donations per donor arose in this way: $27.3 \%$ were given once; $40.9 \%$, two or three times and $31.8 \%$ were loyal donors that is to say, had already been more than three times. Among blood donors at the moment of the survey, $87.6 \%$ were willing to make a new blood donation.

To the question of who can donate blood? Opinions were varied: $10.3 \%$ responded that a person aged 18 or older could donate blood and $36.1 \%$ of a person in good health can donate blood. Eight percent of people respectively gave an answer that only candidates of blood type $\mathrm{O}$ and compatible with recipients and people who had a lot of blood could donate blood. But 2.2\% of respondents said that no one could give blood. This response was given by the witnesses interviewed Jehovah. Furthermore $17.3 \%$ of respondents did not know that can be a donor blood. Other considerations were advanced that only young people can donate blood (2.2\%); single parents (1.4\%); anyone (6.0\%), people who eat well (2.4\%), a voluntary detected (6.0\%) and (1.2\%) a person with good behavior. 
Table 2. Practices, attitudes and knowledge about blood donation and blood transfusion in the population of Bukavu, DRC.

\begin{tabular}{|c|c|c|}
\hline & Number & Percent \\
\hline Design blood & 415 & \\
\hline Fuel of the body & 185 & 44.6 \\
\hline Sacred & 47 & 11.3 \\
\hline Lifeblood & 183 & 44.1 \\
\hline Knowledge about the practice of giving blood & 413 & \\
\hline Yes I do & 162 & 39.2 \\
\hline I do not & 251 & 60.8 \\
\hline Know about the existence of adverse effects associated with blood transfusion & 161 & \\
\hline Yes I do & 108 & 67.1 \\
\hline I do not & 53 & 32.9 \\
\hline Did you follow the sensitization & 162 & \\
\hline Yes I did & 110 & 67.9 \\
\hline I did not & 52 & 32.1 \\
\hline Printing on awareness sessions to donate blood & 110 & \\
\hline Uninformative & 10 & 9.0 \\
\hline Good & 50 & 45.5 \\
\hline Very good & 50 & 45.5 \\
\hline Know about the storage location of blood bags & 413 & \\
\hline PBTC & 19 & 4.6 \\
\hline Public hospital & 270 & 65.4 \\
\hline Private hospital & 11 & 2.7 \\
\hline Do not know & 113 & 27.3 \\
\hline Know about the existence of PBTC in Bukavu & 414 & \\
\hline Yes I do & 57 & 13.8 \\
\hline I do not & 357 & 86.2 \\
\hline Attitude with respect to the blood & 162 & \\
\hline In agreement & 138 & 85.2 \\
\hline Disagreement & 8 & 4.9 \\
\hline Indifferent & 16 & 9.9 \\
\hline Willingness to donate blood & 416 & \\
\hline Yes I do & 247 & 59.4 \\
\hline I do not & 169 & 40.6 \\
\hline Motivation to donate blood & 247 & \\
\hline Money & 31 & 12.6 \\
\hline Volunteer & 163 & 66.0 \\
\hline Pressure doctor & 5 & 2.0 \\
\hline For a family member & 48 & 19.4 \\
\hline
\end{tabular}


Table 3. Analysis of practices, attitudes and knowledge about blood donation and blood transfusion in the socio-demographic characteristics among respondents in Bukavu.

\begin{tabular}{|c|c|c|c|c|c|c|c|c|c|c|}
\hline & \multicolumn{2}{|c|}{$\begin{array}{l}\text { Knowledge on the } \\
\text { practice of gift }\end{array}$} & \multicolumn{2}{|c|}{$\begin{array}{l}\text { Already donate blood } \\
\text { once in life }\end{array}$} & \multicolumn{2}{|c|}{$\begin{array}{l}\text { Be willing to } \\
\text { donate }^{* *}\end{array}$} & \multicolumn{2}{|c|}{$\begin{array}{l}\text { Knowledge of the adverse } \\
\text { effects associated with } \\
\text { blood transfusion }\end{array}$} & \multicolumn{2}{|c|}{$\begin{array}{l}\text { Positive attitude } \\
\text { to the blood } \\
\text { transfusion }\end{array}$} \\
\hline & n (\%) & $p$ & n (\%) & $p$ & n (\%) & $p$ & n (\%) & $p$ & n (\%) & $p$ \\
\hline Sex & & 0.6 & & 0.28 & & 0.16 & & 0.63 & & 0.1 \\
\hline Female & 159 (40.9) & & $65(60.0)$ & & 159 (63.5) & & $65(69.2)$ & & 65 (90.8) & \\
\hline Male & $253(38.3)$ & & 97 (51.5) & & $256(56.6)$ & & $96(65.6)$ & & 97 (81.4) & \\
\hline Profession & & 0.57 & & 0.89 & & 0.9 & & 0.41 & & 0.43 \\
\hline Public sector & 35 (42.9) & & $15(60.0)$ & & $35(60.0)$ & & $15(60.0)$ & & $15(80.0)$ & \\
\hline Private sector & $132(35.6)$ & & $47(53.2)$ & & 133 (29.4) & & 47 (74.5) & & 47 (80.9) & \\
\hline Unemployed & $246(40.7)$ & & $100(55.0)$ & & 248 (59.3) & & 99 (64.6) & & $100(88.0)$ & \\
\hline Level of education & & $<0.001$ & & 0.12 & & 0.52 & & 0.21 & & 0.66 \\
\hline Primary-illiterate & $34(8.8)$ & & $3(66.7)$ & & 34 (64.7) & & $3(100.0)$ & & $3(66.7)$ & \\
\hline Secondary & $292(37.7)$ & & $110(60.0)$ & & 295 (57.6) & & $109(63.3)$ & & $110(85.5)$ & \\
\hline University & 87 (56.3) & & 49 (42.9) & & $87(63.2)$ & & 49 (73.5) & & 49 (85.7) & \\
\hline Religion & & $<0.001$ & & $0.75^{*}$ & & 0.06 & & $0.77^{*}$ & & $0.05^{\circ}$ \\
\hline Christian & 349 (43.3) & & $151(55.6)$ & & 352 (61.1) & & $150(66.7)$ & & $151(87.4)$ & \\
\hline Unchristian & $56(16.1)$ & & $9(44.4)$ & & $56(48.2)$ & & $9(77.8)$ & & $9(55.6)$ & \\
\hline
\end{tabular}

*Exact Fischer. ${ }^{* *}$ Analyses of variables practice knowledge donation and willingness to donate are made throughout the entire sample, while those on the variables already donate blood, knowledge of adverse effects related to transfusion and positive attitude to blood transfusion are those who know the practice of donating blood.

\section{Discussion}

\subsection{Blood Safety}

The need for blood in medical practice only increase [8]-[11], this implies a greater mobilization of the population for voluntary blood donation to recruit potential donors. DRC received interventions in this direction. Interventions blood safety are funded as part of the fight against AIDS in the country. They are to support one of the stages of the transfusion chain depending on the context: the organization of community awareness about blood donation and leadership development donor associations and healthcare providers. In addition, this funding helped supply inputs and cold chain equipment and organize other activities such as blood drives, qualification, storage and distribution of blood products, supervision and quality assurance.

This study was designed to assess the knowledge, attitudes and practices regarding blood donation in the general population to develop appropriate strategies and maximize efforts for a steady supply of blood products free of any risk in hospitals. The methodological limitations that may cause potential bias due to select streets and people from place to place. These people may have the same information, attitudes and habits because of their proximity. Nevertheless it has the merit of making an inventory on blood donation and transfusion in the general population.

\subsection{General's Characteristics of Respondents and Knowledge about Blood Donation}

Our study enlisted a sample dominated by males, Christians, young age and a high-school education. It is consistent with the characteristics of the Congolese population [12]. Nevertheless sex considered in our investigation is that the head of household giving a distribution somewhat different from that of the Congolese general population which is characterized by a distribution of $50.1 \%$ female and $49.9 \%$ male. This can be explained by the fact that during investigations or interviews are more often men who volunteer to answer questions. The survey shows that $39 \%$ of respondents were aware of the practice of giving blood. Of those who knew the prac- 
tice of donating blood 32.3\% had awareness sessions. These low ratios indicate that the means used to date have not achieved the expected objectives [13]. Possible reasons are, firstly, the financing of these activities is selective and insufficient, decided at the top of the health system without knowing the ground reality and also a sprinkling that involves funding of any overall transfusion chain instead of making a choice on one of the steps to strengthen in the transfusion chain and maximize.

\subsection{Attitude to Blood and Blood Donation's Practices}

We found the design of the blood in the study of Lome [7] and Central African Republic [14]. Blood is considered a fuel and source of life, it has a religious connotation and even traditional as confirmed Agbovi et al. [7]. The consequence is that giving blood is like giving life, strength but also lose some of its physical and spiritual strength to be vulnerable to disease and witchcraft, as regular donations are synonymous with regular sacrifice, not conceivable for a stranger. An anonymous and voluntary donation seems to be difficult to accept but a gift made to a known person who is held in life means caring and strengthens social bonds in the traditional environment. Motivations to donate blood, most often mentioned were the volunteer 66.0\% against 31.7\% donation to a family member or against money. Motivation for voluntary blood donation in Dakar was 43\% [15], Saudi $36.7 \%$ [8] while in the USA's intentions were benevolent gift to $75 \%$ - $87 \%$ [16]. The proportion of motivation for volunteering found in our study is not consistent with the rate of the country is less than $40 \%$ and towns in the interior of our province where the proportions of family gifts are high. This difference is explained by a more advanced network of associations of blood donors in urban areas than in rural areas in the province and by the fact that national development, taking into account data from all areas health. Among them the majority do not have an organization of blood donation to the required standards. Given this unsatisfactory figure volunteer yet advocated in national politics transfusion country it is necessary to put in place strategies to transform the initially favorable attitude in real practice [7] subsequently transform donors replacements of regular volunteers and donors in order to raise general population especially those who are reluctant.

It begs the question whether these considerations are not responsible for not achieving the strategic objectives of blood services in the DRC. Indeed, transfusion requirements of the country are estimated at more than 450,000 transfusions annually. But needs covered from 2009 to 2011 were respectively measured at 54\%, 66\% and $71 \%$ [17]. In terms of blood donation, the evolution of voluntary donations is as follows: $33.6 \%$ in 2009 , 35\% in 2010 and 33\% in 2011; while the family gifts is 61.2\% in 2009. 60\% in 2010 and 63\% in 2011, the proportion of paid donations was 5.2\% in 2009, 5\% in 2010 and 4\% in 2011 This situation is related to several factors, among which the most important are: the geographical extent of the country with structures not suitable bases, the importance of the need for safe blood products with a non-mastery of all parameters, low mobilization funding for the activities of blood safety. All this has implications for several types: blood shortage of quality in hospitals. This thesis is supported by the routine data that tell us that 73\% in 2010 and 68\% in 2011 units transfused throughout the country have been a qualification according to the national protocol its means 4 were tested for infectious markers strategic: both to HIV, hepatitis B and C and syphilis. The respondents mentioned some reasons for refusing the donation, these reasons are found in other studies in Africa or elsewhere in Lome Agbovi et al. in 2006 [7], in Lagos Olaiya et al. in 2004 [9], Umeora et al. in rural Nigerian in 2005 [18], Misje et al. in Oslo in 2005 [19], Duboz and Cunéo in France in 2010 [20], Boulware et al. in Maryland in 2002 [21].

These reasons are: fear of contracting diseases especially HIV, religious beliefs, sales collected by the medical staff, fear of test result for HIV blood. The reasons for refusal to donate blood can be summarized as a lack of information which is normally reduced by a good organization of awareness sessions. It would explain why the major anxiety of non-associated donors to donate blood boils to think that this is a cold act, intrusive and complicated and that the destination of the blood is poorly realized. It must also be said that giving blood is a very intimate personal decision, we do not share. However, the act itself can or should be shared thereby increase its usability and especially to reduce the cold and scary character. So having the transfusion service management must invest to multiply blood drives in associations (collective atmosphere), multiply the sensitization by trained for this purpose as sociologists, psychologists, anthropologists and communicators because until present in the DRC, these outreach services are performed by doctors, nurses and lab technicians with ongoing training in awareness seems to be limited. But we should make it really professional associations donors with a clear partnership [22] [23].

Our study does not provide information on the underlying causes of refusal to donate blood in the population 
or the reluctance of former blood donors in good health, to return to donate blood. Future especially qualitative surveys are recommended to help understand and improve the practice of donating blood and loyalty to donate blood [11] in our country. We found the same channels as those identified by awareness Misje et al. [19] it is the media, churches and friends. So it should be recommended to focus awareness on the reasons for refusal to give blood to convince otherwise, incorporate blood donation in educational programs in the media and even in youth programs in some churches [7].

We should also consider the message of invitation to donate blood, the themes of national or global celebrations local days of blood donation. The message must be simple, clear on the usefulness and future of blood, on the recognition of merit blood donor. Messages must call on the need for blood in hospitals [24] [25]. The retention rate was $31.8 \%$, it is higher than the national average estimated from routine data in RDC 6.3\% [17]. This percentage is very low compared to that found in Saudi [8] where there were $41.8 \%$ of faithful donors. The low retention rate of our study and the country suggests that donors are not likely to return to donate blood. We should seek the reasons for discouragement to better retain donors [7] and encourage donors to continue to donate [4]. This will involve exploring the effectiveness of taking an appointment with a reminder to first donors, which would foster commitment and regularity of the gift while maximizing organizational and time management during collection blood. Other techniques for retention are: listening to donors outside the framework of transfusion service, establish a long-distance relationship with donors and rigorous systematization of post donation [24]-[26] information.

\section{Conclusion}

This study allowed us to identify the factors that push people not to donate blood or not to continue to donate blood. Knowing the level of understanding and attitudes of the population to blood donation and transfusion, should stimulate thinking on new strategies to implement in services with transfusion support to mobilize population and increase regular blood donation to meet the enormous need for blood in hospitals.

\section{References}

[1] Nébié, K.Y., Olinger, C.M., Kafando, E., Dahourou, H., et al. (2007) Lack of Knowledge of Blood Donors in Burkina Faso (West Africa); Potential Obstacle to Transfusion Security. Transfusion Clinique et Biologique, 14, 446-452. http://dx.doi.org/10.1016/j.tracli.2007.12.005

[2] Mbendi Nlombi, C., Longo-Mbenza, B., Mbendi Nsukini, S., Muyembe Tamfum, J.J., et al. (2001) Prévalence du VIH et de l'antigène Hbs chez les donneurs de sang. Risque résiduel de contamination chez les receveurs de sang à Kinshasa-Est, République Démocratique du Congo. Médecine Tropicale, 61, 139-142.

[3] Giraud, Ch., Korach, J.M., Andreu, G., Lacaze, C., et al. (2002) Le don du sang. Transfusion Clinique et Biologique, 9, 168-178. http://dx.doi.org/10.1016/S1246-7820(02)00243-4

[4] Follkal, G., Bigey, F., Wagner, A., Vives, C., et al. (1998) Evaluation de mesures destinées à développer la régularité du don de sang. Transfusion Clinique et Biologique, 5, 241-250. http://dx.doi.org/10.1016/S1246-7820(98)80368-6

[5] Kocher, P. (1994) Recrutement des donneurs de sang: Nouvelle stratégie. Médecine et Hygiène, 52, 1000-1005.

[6] Beauplet, A., Danic, B. and Aussant-Bertel, F. (2003) Medical Selection of Blood Donors: Risk Prevention for the Recipient. Transfusion Clinique et Biologique, 6, 371-431. http://dx.doi.org/10.1016/j.tracli.2003.07.001

[7] Agbovi, K.-K., Kolou, M., Fétéké, L. and Haudrechy, D. (2006) Étude des connaissances, attitudes et pratiques en matière de don de sang. Enquête sociologique dans la population de Lomé (Togo). Transfusion Clinique et Biologique, 4, 260-265. http://dx.doi.org/10.1016/j.tracli.2006.06.002

[8] Alam, M. and El Din Masalmeh, B. (2004) Knowledge, Attitudes and Practices Regarding Blood Donation among the Saudi Population. Saudi Saudi Medical Journal, 3, 318-321.

[9] Olaiya, M.A., Alakija, W., Ajala, A., Olatunji, R.O., et al. (2004) Knowledge, Attitudes, Beliefs and Motivations towards Blood Donations among Blood Donors in Lagos, Nigeria. Transfusion Medicine, 14, 13-17. http://dx.doi.org/10.1111/j.0958-7578.2004.00474.x

[10] Wiwanitkitll, V. (2002) Knowledge about Blood Donation among a Sample of Thai University Students. Vox Sanguinis, 83, 97-99. http://dx.doi.org/10.1046/j.1423-0410.2002.00209.x

[11] Mathew, S.M., King, M.R., Glynn, S.A., Dietz, S.K., Caswell, S.L. and Schreiber, G.B. (2007) Opinions about Donating Blood among Those Who Never Gave and Those Who Stopped: A Focus Group Assessment. Transfusion, 47, 729-735. http://dx.doi.org/10.1111/j.1537-2995.2007.01177.x 
[12] Institut National de la Statistique et Fonds des Nations Unies pour l'Enfance (2011) Enquête par Grappes à Indicateurs Multiples en République Démocratique du Congo (MICS-RDC 2010). Rapport Final, 19-25.

[13] Tagny, C.T., Diarra, A., Yahaya, R., Hakizimana, M., Nguessan, A., Mbensa, G., et al. (2009) Le centre de transfusion, le donneur de sang et le sang donné dans les pays d’Afrique francophone. Transfusion Clinique et Biologique, 16, 431-438. http://dx.doi.org/10.1016/j.tracli.2009.07.005

[14] Gobatto, I. (1996) Donating Blood in the Time of AIDS. Some Ideas from a Study in Bangui (Central African Republic). Current Research. Societes d'Afrique et SIDA, 13, 8-10.

[15] Duboz, P., Macia, E. and Cunéo, B. (2010) Sociodemographic and Attitudinal Factors to Blood Donation in the Urban Population of Dakar, Senegal. Transfusion, 50, 2713-2720. http://dx.doi.org/10.1111/j.1537-2995.2010.02750.X

[16] Glynn, S.A., Kleinman, S.H., Schreiber, G.B., Zuck, T., McCombs, S., Bethel, J., et al. (2002) Motivations to Donation Blood: Demographic Comparisons. Transfusion, 42, 216-225. http://dx.doi.org/10.1046/j.1537-2995.2002.00008.x

[17] Programme National de Transfusion Sanguine en République Démocratique du Congo, Rapport Annuel, Kinshasa 2009-2010-2012.

[18] Umeora, O.U.J., Onuh, S.O. and Umeora, M.C. (2005) Socio-Cultural Barriers to Voluntary Blood Donation for Obstetric Use in a Rural Nigerian Village. African Journal of Reproductive Health, 9, 72-76. http://dx.doi.org/10.2307/3583413

[19] Misje, A.H., Bosnes, V., Gåsdal, O. and Heier, H.E. (2005) Motivation, Recruitment and Retention of Voluntary NonRemunerated Blood Donors: A Survey-Based Questionnaire Study. Vox Sanguinis, 89, 236-244. http://dx.doi.org/10.1111/j.1423-0410.2005.00706.x

[20] Duboz, P. and Cunéo, B. (2010) How Barriers to Blood Donation Differ between Lapsed Donors and Non-Donors in France. Transfusion Medicine, 20, 227-236. http://dx.doi.org/10.1111/j.1365-3148.2010.00998.x

[21] Boulware, L.E., Ratner, L.E., Ness, P.M., Cooper, L.A., Campbell-Lee, S., LaVeist, T.A. and Powe, N.R. (2002) The Contribution of Sociodemographic, Medical, and Attitudinal Factors to Blood Donation among the General Public. Transfusion, 42, 669-678. http://dx.doi.org/10.1046/j.1537-2995.2002.00120.x

[22] Daigneault, S. (2007) Le marketing dans l'univers du don de sang. Transfusion Clinique et Biologique, 14, $147-151$. http://dx.doi.org/10.1016/j.tracli.2007.04.001

[23] Courbil, R., Chenus, F., Julien, H., Ruyer-Dumontier, P. and Garraud, O. (2008) Guide de partenariat pour le bon déroulement d'une collecte de sang. Transfusion Clinique et Biologique, 15, 160-167. http://dx.doi.org/10.1016/j.tracli.2008.07.003

[24] Calléa, N., Plainfossé, C., Georget, P., Sénémeaud, C. and Rasonglès, P. (2011) La psychologie sociale de la persuasion au service de la fidélisation des donneurs: Modèles de conception de messages d'invitation au don. Transfusion Clinique et Biologique, 18, 565-569. http://dx.doi.org/10.1016/j.tracli.2011.04.005

[25] Calléa, N., Plainfossé, C., Georget, P., Sénémeaud, C. and Rasonglès, P. (2011) La psychologie sociale de la persuasion au service de la fidélisation des donneurs: L'importance de donner du sens au dernier don. Transfusion Clinique et Biologique, 18, 559-564. http://dx.doi.org/10.1016/j.tracli.2011.04.006

[26] Pesavento, S. and Bégué, L. (2011) Introducing Marketing Strategies and Techniques into the Field of Voluntary Blood Donation, to Meet the Rise in Blood Demand. Transfusion Clinique et Biologique, 18, 198-205. http://dx.doi.org/10.1016/j.tracli.2011.02.009 


\section{Questionnaire}

1) Sex_ Age___ Occupation___ Level of study__ Religion

2) Design of blood: blood, fuel of the body; blood, sacred; blood for life.

3) Knowledge on blood donation: Yes or No.

4) Knowledge of the practice off blood donation: Yes or No.

5) What the sources of information:

Media, friends; public awareness, schools, churches; by the association.

6) Did you follow the sensitization: Yes or No.

Impressions of respondents on educational sessions: good, good, uninformative.

7) Knowledge of places of collection and storage of blood in Bukavu:

Provincial blood transfusion center (PBTC), private hospitals, hospital officials.

8) Do you know the provincial blood transfusion center (PBTC): Yes or No.

9) Attitudes to blood transfusion: approval, disapproval, indifference.

10) Disposition of respondents to give blood: Yes or No.

11) Have you ever donate blood: Yes or No.

How many times in your life

12) What is the motivation to donate blood for volunteer help a family member, the doctor told me to give as much in my body for money.

13) What are the reasons for refusal to give blood: lack of information, fear of getting sick after the donation, sale of collected blood, prohibited by religion, afraid of the results of HIV, fear of infection, other.

14) Would you be paid after donation: Yes and No. 
Scientific Research Publishing (SCIRP) is one of the largest Open Access journal publishers. It is currently publishing more than 200 open access, online, peer-reviewed journals covering a wide range of academic disciplines. SCIRP serves the worldwide academic communities and contributes to the progress and application of science with its publication.

Other selected journals from SCIRP are listed as below. Submit your manuscript to us via either submit@scirp.org or Online Submission Portal.
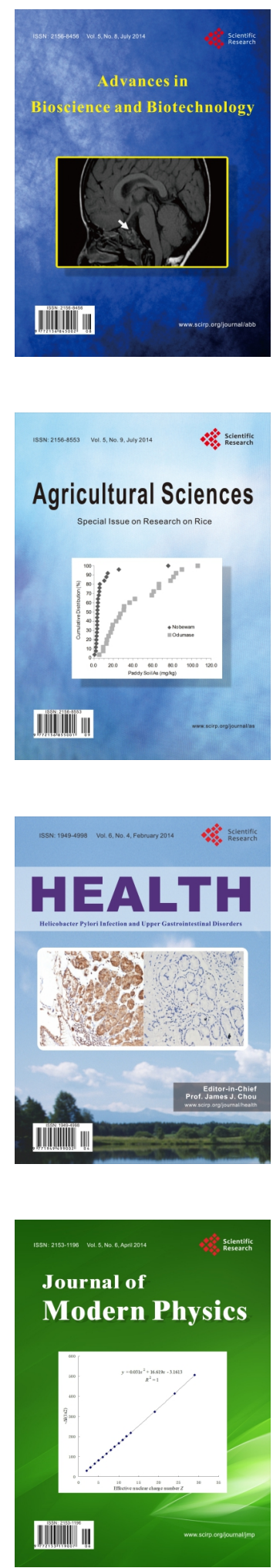
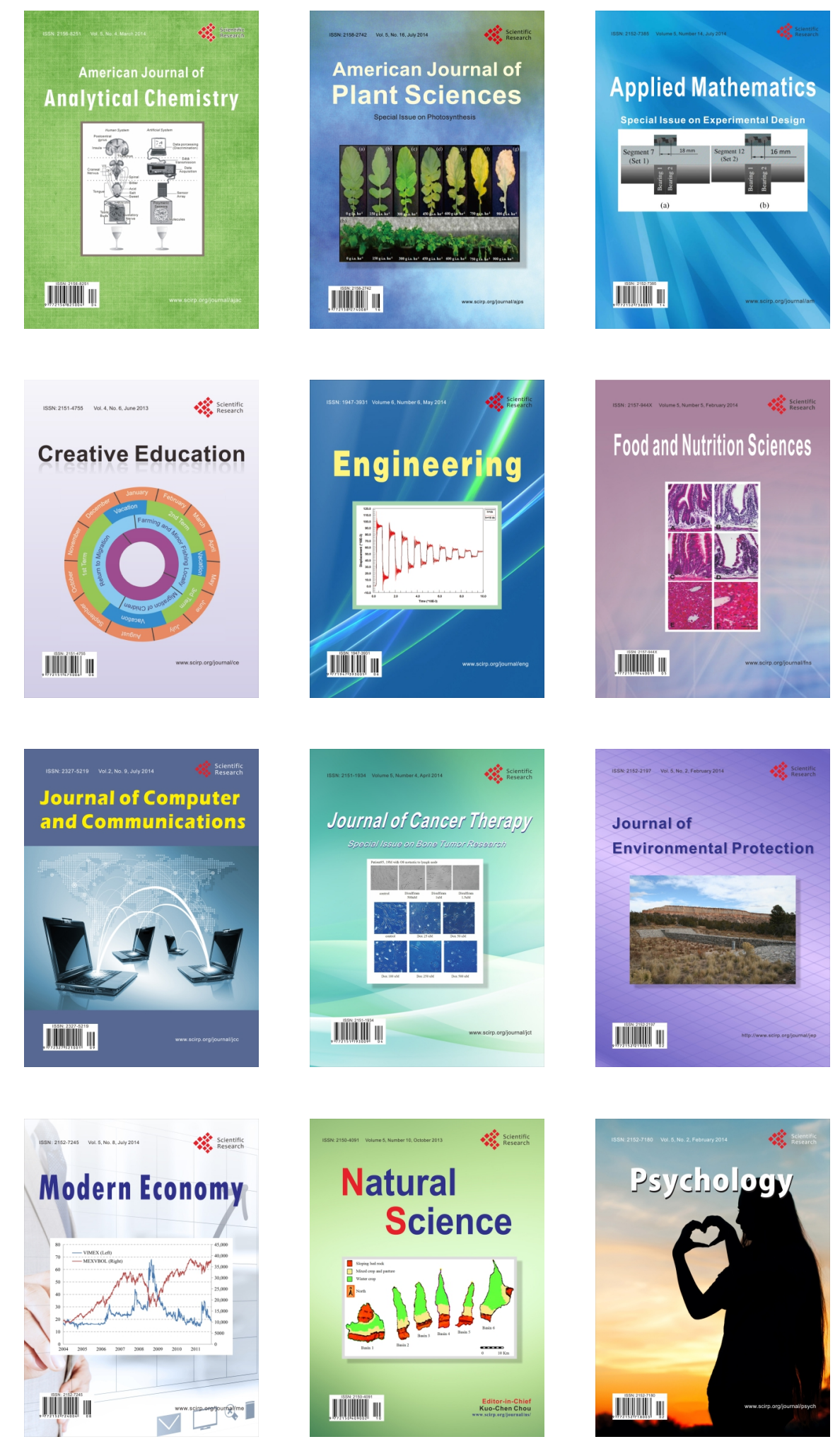